\title{
Academic Law Libraries \& Management of Resources for National Development In Nigeria
}

\author{
${ }^{1}$ Anyaegbu, Mercy Ifeyinwa ${ }^{2}$ Obiozor-Ekeze, Roseline Nkechi \\ ${ }^{1}$ Faculty of Law Library, Nnamdi Azikiwe University Awka \\ ${ }^{2}$ Festus Aghagbo Library, Nnamdi Azikiwe University Awka
}

\begin{abstract}
The vision of the administration under Goodluck Jonathan is packaged in Transformation Agenda which is aimed at holistic overhaul of every segment of national life. Members of the legal profession have a critical role to play towards the success of the transformation agenda. However, a lawyer can only be as good as the system of legal education that produced him; hence the need to revive and reposition the legal education framework. The paper discussed the responsibility of academic law libraries in the shaping of legal practitioners and towards the academic community. It $x$ rayed the challenges facing these libraries and made recommendations for improved law library services in Nigeria.
\end{abstract}

Key Words: Academic Law libraries, Transformation Agenda, Resource Management, National Development

\section{Council for Innovative Research}

Peer Review Research Publishing System

Journal: International Journal of Management \& Information Technology

Vol.3, No.3

editor@cirworld.com

www.cirworld.com, member.cirworld.com 


\section{OVERVIEW OF LAW LIBRARIES AND LEGAL EDUCATION}

Academic law libraries are libraries established in faculties of law in institutions of higher learning such as the university and the Nigerian Law School. The history of academic law in Nigeria libraries can be traced to the establishment of faculties of law in the universities. In Nigeria, the training of lawyers starts properly at the university. Legal education in Nigeria is two fold - academic and vocational. The academic stage, which starts at the university, leads to the award of Bachelor of Laws degree (LL.B). The vocational stage is undertaken at the Nigerian Law School. At the successful completion of the law school programme, a lawyer is entitled to enroll as both a barrister and solicitor of the Supreme Court of Nigeria.

This implies that a lawyer can only be as good as the system of legal education that produced him. In the words of Sidney Littlewood (2004), an under-trained and under-educated lawyer is a menace to his client, a danger to himself ... of little use to his society and a disgrace to his profession. The import of the above statement underscores the dangers inherent in a deficient system of legal education. As Onadeko (2006) observed, legal education, academic as well as vocational, is a vital ingredient that affects the quality of our justice system and the role of lawyers in the political, economic and social development of our country. If our legal education is poor, we cannot expect to produce world-class jurists, practitioners or judges. There is therefore a direct relationship between the quality of our legal education and the quality of our lawyers.

Academic law libraries are not only essential but crucial to the study and practice of the legal profession. According to the NUC Benchmark for Legal Education (2004), the undergraduate academic law training should equip the student to have a broad general knowledge and exposure to other disciplines in the process of acquiring legal education. The academic legal education is therefore two-pronged. First it serves as a stimulus to stir the students into the critical analysis and examination of the prevailing social, economic and political system of his community. Secondly it should serve as an intellectual exercise aimed at studying and assessing the operation, efficiency and relevance of various rules of law in society.

There is now a shift of emphasis in the learning environment from lecturer- dominated to student centred. This is aimed at empowering the student to be self reliant in the sourcing and utilization of information resources during research. It is often said that the best lawyers are those who know best where and how to find the law as the need arises. The enabling environment to achieve this can only be realized through proper utilization of resources at the law library. The Council of Legal Education therefore recommends that lectures in various faculties of law in Nigeria should end by $4.00 \mathrm{pm}$ to enable law students' ample time to study on their own. The essence is to discourage over reliance on lecturer notes and handouts.

\section{THE MAIN THRUST OF TRANSFORMATION AGENDA}

The literary meaning of transformation is a complete change from one situation (usually undesirable) to another (the desired). It is a total departure from the old order of doing things to a complete new one. Thus transformation cannot be achieved if not planned and consciously executed. It is a deliberate effort that requires practical realistic action or tasks needed to achieve a desired goal.

Since independence in 1960, the various administration that have mounted the leadership of this great country Nigeria have conceived and designed different long term policies aimed at national development. These include National Development Plans, Structural Adjustment Programme (SAP), NEEDS, and Vision 2020 etc. These development initiatives have in one way or the other affected positively the economy of this country. But it seems that each development strategy dies with the administration that gave birth to it. The constant transition from one strategy to another may not be far fetched. Probably they failed to achieve the desired effect on the development of Nigeria.

The vision of the present administration under President Goodluck Jonathan is packaged in Transformation Agenda which is aimed at having a holistic overhaul of segment of the national life - political, economic and social life. It draws inspiration from Vision 2020 and the 1st National Implementation Plan (NIP). According to Anyim (2012), it places emphasis on attitudinal change along the path of patriotic zeal and commitment. It involves a resolute determination of government/citizens to systematically upgrade their national development index. It connotes the participation of all in the process that enhances the general well-being by improving the economic, political and social environment. Transformation of a country as Anyim (2012) further observed, connotes rapid incremental changes in the development indices of a country. This will comprise of comparatively high Gross Domestic Product (GDP) and high Human Development Index (HDI), achieved through deliberate intervention policies, appropriately and faithfully implemented.

Specifically, the policy thrust of the Transformation Agenda can be outlined as follows:

1. Electoral Legitimacy: The significance of electoral legitimacy is that the government that emerges through free, fair and credible elections is expected to be accountable to the citizens that have entrusted the exercise of political authority to it. It is hoped that if the electorate could demand accountability from the leaders they elected (in the real sense of it), it will serve as a key ingredient for accelerated national development between 2011 and 2015.

2. Peace and Security: Assuring peace and security within the territorial area of a state is an incontrovertible precondition for development. This is based on the fact that there can be no peace without development. The creation of the Ministry of Niger Delta and the recent concerted efforts of government towards achieving peace in the Northern states forms part of this policy thrust.

3. Job Creation Initiatives: These initiatives include implementing a youth employment safety net support programme, vocational training, development of industrial clusters, reviewing of tertiary institutions curricular to align with industry job requirements and promotion of apprenticeship experience programmes, joint ventures and implementation of mandatory skills transfer to Nigerians by foreign construction companies. 
4. Public Expenditure Management: Government will entrench a culture of accountability by beginning to sanction and prosecute public officers that breach established financial management rules and regulations as well as engage stakeholders early in budget preparation processes.

5. Good Governance/Rule of Law: Under the transformation agenda, policies and programmes are directed at addressing governance challenges. These are focused on the public service, security, law and order, the legislature, anti-corruption institutions, the judiciary and support for private sector investment. All this is geared towards maximizing benefits the citizenry will derive from governance through prudent and effective use of public fund. Independence of the judiciary and speedy dispensation of justice is part of the policy thrust of this administration.

6. Foreign Policy and Diplomacy: The present administration is determined through its foreign policy to reposition Nigeria in the comity of nations.

7. The Legislature: The thrust of the policy and the performance of the legislature will facilitate the creation of a dynamic, constitutionally effective and public responsive legislature that is proactive in its legislative duties. This administration is committed to a robust relationship with every arm of government with a firm recognition of their independence.

8. Human Capital Development, Health and Education: This administration is mindful of the strategic role human capital development plays in the socio-economic development of a nation; the core areas are in education, health, labour and employment. The essence is to empower the human resources to be knowledgeable, skilled, productive and healthy. The full utilization of other resources (material) to engender growth and development is dependent on the development of the human resources. Since the transformation agenda is a relatively new policy of the government, the academic law library has a key role to play towards its realization. The workforce should be informed about the policy. They should be empowered through regular training and manpower development whenever the need arises. They should be motivated through regular and adequate salary and better conditions of service. Efficient and dedicated staff should be hired and retained to ensure continuity.

9. Agriculture, Food Security, Oil and Gas Sector: These are other critical areas of the transformation agenda that assist in developing the country since most of our foreign earning are derived from these sectors.

10. Infrastructural Development: Critical infrastructure deficit in the country is particularly worrisome in key areas of development such as power, transportation, housing, ICT etc. The government is determined in this policy to increase power generation, transmission and distribution. Electricity supply in most universities including the academic law libraries is grossly inadequate. Providing electricity supply through alternative power supply such as electricity generating set is capital intensive.

11. ICT: Information and Communication Technology is also a crucial policy thrust of the Transformation Agenda. Gladly, a ministry has been created in this regard. The application of ICT in law library services is not negotiable. If every Supreme Court decision taken in Nigeria can be accessed online same day in Library of Congress, (in America). What can be said about the absence of such court decisions in Nigerian university law libraries in the country where the court decision was taken? Certainly IT facilities will improve the quality of information provision in the academic law libraries.

\section{RESOURCE MANAGEMENT IN LAW LIBRARIES}

Simply put, a resource is a source of aid or support that may be drawn upon when needed. It can also be described as an action or measure which one can deploy in times of emergency or need. Resource management is the process of using organization resources in the most efficient way possible. These resources can include tangible resources such as goods and equipment, financial resources and labour resources such as employees. Resources management also includes intangible resources such as ideas and information.

Resources in a law library comprises of human and material resources. Human resources represent the workforce. There are different categories of staff that work in the law library. Ideally staff that work in the academic law library can be categorized into professional, para-professional and general duty staff. Professional staff of the law library comprise of all librarians that have degrees in librarianship and probably in law. The paraprofessionals comprises of the library officers, library assistants, system analyst etc. The general duty staff as the name implies have no prior orientation/qualification in library operations. They can be transferred to any other department in the institution. Staff in this category includes secretaries, office attendants, clerical staff, janitorial staff etc.

\section{RESOURCE MANAGEMENT FOR NATIONAL TRANSFORMATION}

1. Libraries are the academic nerve centre of institutions of higher learning: The traditional role of every library and the law library in particular is the provision of services to clientele. The academic law library was designed to provide for the needs of the legal profession. Users of the law library include the law students, law lecturers and al persons interested in legal research. Academic law libraries can only render these services effectively by building a balanced legal collection. Building of a balanced collection will require certain profession skills and competence. These include:

- adequate knowledge of basic legal sources

- prompt acquisition of new materials

- acquisition of variety of information sources

- keeping abreast of changes in the law (both within Nigeria and at international circle).

2. Teaching and Research: The three basic academic activities that go on at faculties of law are teaching, learning and research. The Council of Legal Education insists on having a standard legal collection as a condition precedent for granting accreditation to faculties of law in Nigeria. Skills on how to harness best the knowledge in these 
collections can only be acquired if the law library takes the responsibility of educating their patrons on how to use the resources. Legal research is aimed at breaking new grounds in the field of law. The law librarian can show leadership by having mastery of basic research skills such as:

- ability to initiate or interpret research topics

- having a firm grasp of the research process

- ability to source and package information resources (i.e. knowledge and usage of existing legal database).

- ability to collate, analyze and interpret research findings

- ability to apply properly research findings.

3. Electoral Legitimacy: Electoral legitimacy can only be realized if the electorates are properly informed. Nigerian citizens ought to know their rights and their role in the electoral process. These are contained in the Constitution and other statutory instruments. The academic law library should acquire these documents as and when due, process them and make them available to users on demand. Every constitutional amendment should be reflected in the collection. Information on election should be publicized in the institutions publications such as their bulletin, senate proceedings etc.

Similarly, the academic law library should monitor debates and resolutions going on at both the national and state houses of assembly. It should be a powerhouse where update on election matters and parliamentary decisions can be easily accessed. This brings to the fore the need to acquire gazettes, bills and laws as soon as they are made. The publications of the various regulatory organs and anti graft agencies in charge of checking corrupt practices in the country should be acquired.

4. Peace and Security : Maintaining peace and security is one of the cardinal principles of the Transformation Agenda. The problem of insecurity is a thorny issue in Nigeria in the recent time. Report of various bomb blasts, killings and social disturbances in various parts of the country are being reported in newspapers and magazines. Committees of Enquiry are being set by the government from time to time. These media reports have a way of heating the polity. It breeds rumour and dissemination of false information.

The Government both at the federal and state levels are making concerted effort to check these problems. Those government publications that counter this false information should be promptly acquired, processed, indexed and publicized to the academic community. Current Awareness Services and Selective Dissemination of Information are referral services needed to enlighten the academic community. Sometimes the law library may be required by concerned authorities (sometimes the law court) to tender certified true copies of these documents to the public.

5. Good Governance/Rule of Law: The Transformation Agenda is set to address through its policies and programmes governance challenges. The academic law library should through its collection keep track of the workings of the government. Laudable projects/programmes of the government can be publicized at the billboard of the library and the faculty. Foreign policies on and about Nigeria should be acquired and brought to the notice of students and lecturers in the law faculties.

\section{CHALLENGES}

The Transformation Agenda is realizable. The academic law library like every segment of the Nigerian society has a role to play. However a mirage of problems militates against this role. These include:

1. Paucity of Funds: Paucity of fund is endemic in academic law libraries. Academic law libraries in Nigeria depend on the main university library for its funding. Law competes with other disciplines in the meager financial resources allotted to university library for acquisition of information resources. Most often useful materials needed for prompt service at the law library are not acquired.

2. Administrative Bottleneck in Acquisition Process: The acquisition practices in most academic law libraries in Nigeria do not encourage prompt service delivery. The acquisition practice, which starts at the law library, involves series of bureaucratic process which delay early arrival of requested materials. Experience have shown that sometimes these materials arrive only when their need have elapsed.

3. Autonomy of Academic Law Library: The organizational structure of academic law libraries in Nigeria is such that the law Library which services Faculty of Law is under the control of the University Library. The law librarian is responsible to the university librarian in terms of financial matters. This organizational arrangement affects the book vote, slow down acquisition and administrative processes.

4. Education of Law Librarians:The professional qualification of academic law librarian in Nigeria is so demanding. By Council of Legal Education requirement, the Law Librarian should be a lawyer. This involves a dual degree in law and librarianship. No university in Nigeria offers a degree course in law librarianship. Not less than 10 years is required to acquire both degrees. The big question that begs for an answer is at whose expense? Even when both degrees are acquired, the designation of the law librarian is not spelt out in most Nigeria University Conditions of Service. The law librarian not being a law lecturer is not allowed to practice as a lawyer. This dilemma has put to question the gains of practicing as a law librarian in academic law libraries.

5. Inadequate Human Resources: Resources needed to achieve the Transformation Agenda through the law library require a proper combination of both human and material resources. Adequacy of the human resources is a function of right number and quality. The experience in most academic law libraries is shortage of both professional and non-professional staff to carry out this laudable vision of the government.

6. Poor Infrastructure Development: Accommodation, furniture, equipment, and other infrastructure facilities are grossly inadequate in most institutional law libraries.

\section{SUGGESTION FOR IMPROVEMENT}


The following recommendations are made to enhance effective services at academic law libraries:

1. Improved Funding: All stakeholders/regulatory agencies involved in legal education should form a common front to address the issue of poor funding in academic law libraries. They include, Council of Legal Education, Nigerian Bar Association and even the Nigerian Association of Law Libraries. The Tertiary Education Trust Fund should include academic law libraries as critical area.

2. Autonomy of Law Libraries: A degree of viable autonomy is recommended for academic law libraries. These law libraries should be under the control of the faculty of law instead of the university library. This will reduce the bureaucratic bottleneck in the administrative process.

3. Faculty Status for Law Librarians: Academic Law Librarians should be properly designated to give them academic status like every other academic staff of the faculty of law. There is urgent need to overhaul the curriculum of Library and Information Science professionals to include law librarianship as a course of study at degree level. An alternative would be to redefine the dual qualification required by the Council of Legal Education. These impediments affect the moral of the academic law librarian.

4. Recruitment of More Staff: The right number and caliber of professional and non-professional staff required at the law library will improve law library services. Regular training and staff development programmes will boost staff requirement at the law libraries.

5. Improved Infrastructure Development: Considering the poor infrastructure development at the law libraries, the Council of Legal Education should come up with a new standard in view of current trends. This new standard will focus on accommodation, furniture, equipment and ICT Infrastructure.

6. Distribution of Gazettes/Government Publications: Knowledge of the existence and distribution of the gazette and other government is problematic in Nigeria. A common pool can be created at the six geo-political zones to oversea effective distribution of these publications. Law libraries in Nigeria can also build a consortium in this regard.

\section{SUMMARY}

The academic law library has a crucial role to play in legal education and the transformation agenda. Various challenges, which impede this role, includes paucity of funds; bureaucratic acquisition process; lack of autonomy; education of law librarians; poor staffing and poor infrastructural development. These hindrances can be overcome if certain measures are put in place.

\section{REFERENCES}

[1] Adamolekun, Ladipo (2011) 'A Transformation Agenda for Accelerated National Development' http:/ /ww.w.vanguardngr.com/2011/05/ a-transformation-agenda-for-acc...(accessed 7/19/2012).

[2] Anyim, Pius (2012) Nigeria in Transformation.http://www.osgf.gov.ng//ndex.php?p=SGFSPEECH (accessed on 7/29/2012)

[3] Business

Dictionary.com

(2010)

Resource

Management. http://www'businessdictionary.com/definition/resource-management.htm (accessed on 8/10/2012).

[4] Dada,T (2011) Law Librarianship and Legal Research in the Digital Age. Lagos: NIALS.

[5] Littlewood, Sidney (2004). 'The Legal Profession in African territories' In Essays in Honour of Hon. Justice M. O. Onalaja. Lagos: Diamond Publications.

[6] Mamman, Tahir (2011) "A Review of the Framework of Legal Education in Nigerian Universities" Being a paper delivered at Justice M.M.Akanbi Annual Lecture at University of llorin on $8^{\text {th }}$ November, 2010.

[7] Okiy, Rose (2012) Towards Accelerated Development of Academic Library Services in Nigeria for National Development in the $21^{\text {st }}$ Century. Library Philosophy and Practice http:// unllb.unl.edu/LPP

[8] Onadeko, Olarewaju (2005). 'Accreditation and Legal education in Nigeria'. Being a paper presented at the Nigerian Institute of Advanced legal Studies biennial national workshop for Librarians in Lagos, June 21-23.

[9] Onalaja, M. O. (2010) Problem of Legal Education in Nigeria. Retrieved from http://wwwalmiandco.comPublication/ACCREDITATION

[10] National Universities Commission For Legal Education in Nigeria, 2004. 